\title{
THE EFFECT OF SCHOOL LEADERSHIP EFFECTIVENESS ON TEACHER PERFORMANCE ( A Case Study at SMP Negeri Kota Singkawang)
}

\section{Thaiyibi ${ }^{\text {a) }}$}

\begin{abstract}
This survey study aims to understand effective secondary school leadership towards improving teacher performance in the teaching and learning process. There is no doubt that effective school principals are able to promote faster education improvement. On the other hand, good school leadership has a strong impact on school development and student learning outcomes. To understand how the effectiveness of school leadership on teacher performance, survey research has been successfully carried out in Singkawang City Middle School. The results showed that a very successful educational leadership can influence the whole school community especially teachers and students to achieve higher performance in school organizations. This research proves that the principal's strong leadership can not only influence teachers in teaching but also students in learning as a whole. Therefore, similar research can continue to be carried out so that effective educational leadership can influence the people he dreams of with a high commitment to improve work performance such as teachers, school development and surrounding residents.
\end{abstract}

Keywords: Effective Leadership, Leadership effectiness, Teachers Performance, and High School.

\section{A. Introduction}

One method for improving the quality of human resources is the optimization of quality education services so that educational output may always be improved. Education is also used as a determining factor for the success of a country's development. Furthermore, high-quality education also contributes greatly not only to the progress of a nation, but to the world community in a progressive and independent manner. The condition of the people of such a nation is a huge investment that does not come by itself but with efforts with breakthrough development of means to advance the quality of human resources that can play an important role in welcoming global world civilization.

Speaking of quality and independent education, the first step that must be taken is to improve the quality of teachers in schools because this institution is one of the means to prepare a generation of quality people in an effort to achieve the intended national development goals. To form humans in accordance with national development goals based on Pancasila, one of the most important elements of needs is the preparation of qualified teaching staff. It is believed that the teacher is one of the education components that is crucial for the implementation of the educational process with high output. Therefore, its existence and professionalism are very influential in realizing national education programs. This is in 
accordance with RI Law No. 20 of 2003 concerning the national education system CHAPTER XI article 39, stated that:

1. Educational staff are tasked with carrying out administration, managers, developers, supervisors and technical services to support the education process in the education unit.

2. Educators are professionals who are tasked with planning and implementing the learning process, conducting guidance and training, and conducting research and community services, especially for educators in tertiary institutions. ${ }^{1}$

Therefore, the existing human resources at school, such as school principals, teacher councils, students, administrative staff, and other education staff, are crucial in achieving educational goals, in addition they must be supported by adequate facilities and infrastructure.

The teacher is one component that has an important and decisive role for the implementation of the educational process according to Moh. Uzer Usman, ${ }^{2}$ stated that the task of the teacher as a profession includes educating, teaching and training. Educating means continuing and developing life values, teaching means continuing and developing science and technology. While training means developing skills in students.

Professional teachers not only know, but really carry out what their jobs are in connection with these things. Ani M. Hasan (2003) explained that professional teachers must meet the criteria, among others; (1) have a commitment to students and their learning processes, (2) master in depth the subject matter they teach and teach them to students, (3) are responsible for monitoring student learning outcomes through various means of evaluation, (4) able to think systematically about what he does and learns from his professional environment. Based on data from Bappenas (2001), there are still many teachers who have low abilities in understanding the subjects taught. The results showed that the teacher's understanding ability for each subject was around 57 percent to 77 percent.

One reason for the low ability of teachers to understand subjects is the still low level of teacher qualifications at every level of education. Related to this Jalal and Supriadi (2001) stated that: In reality the quality of teachers is very diverse. Various studies have revealed that the level of mastery of teaching materials and skills in using innovative teaching methods is still lacking. Judging from the level of education, the majority of elementary school teachers, and about half of junior high school teachers and around $20 \%$ of high school teachers are still less educated than required.

That the State Junior High School in the city of Singkawang has not produced satisfying results when viewed from the value of the National Examination results. The Data shows the average value and the percentage passing the national exam SMP Negeri

\footnotetext{
${ }^{1}$ Undang-undang No. 20 Tahun 2003 tentang Sistem Pendidikan Nasional (Bandung: Fokusmedia, 2005).

${ }^{2}$ Moh Uzer Usman, Menjadi Guru Profesional (Bandung: Rosdakarya, 2005).
} 
M. Thaiyibi

Singkawang academic year 2009 / 2010, respectively , 6:32 and $88.12 \%$, the which means not shown satisfactory results. In general, the low quality of education can be caused by various factors, both internal and external to the school. The internal factors of the school include the low quality of educators and the applicable curriculum resulting in low effectiveness of the teaching and learning process, inadequate facilities and infrastructure, uneven distribution of teachers and so on, while external factors that affect the quality of education in schools include the participation of parents students, society in general and the government have not been optimal in working together to support quality education.

Teacher performance through the implementation of their duties as instructors, educators, and trainers of their students is expected to make meaningful contributions to the achievements of educational goals that have been set. However, a person's performance is influenced by many factors including leadership factors. In school organizations the component that plays a very important role and is responsible for the survival of the organization is the Principal as stated in article 12 paragraph 1 PP 28 of 1990 that: The school principal is responsible for organizing educational activities, school administration, fostering other education personnel and utilizing and maintaining facilities and infrastructure.

School principals are teachers who are given additional duties to lead formal education institutions from kindergarten/RA to high school. Educational change is very much determined by the leadership of the principal, without effective leadership of the principal, the process of change cannot be achieved by considering and considering the important role of the principal, the Minister of National Education issued Minister of National Education Regulation No . 28 of 2010 concerning the affirmation of teachers as headmasters / madrasas. With the issuance of this Ministry of Education, the desire to raise and desire to be a school principal can be minimized as a payment for political contracts, because it must go through a strict, objective, transparent and accountable mechanism so that later it will truly produce quality school principals.

In its activities the principal can instruct subordinates what to do, can influence how to carry out his orders. At the assignment stage, the principal must provide clear direction and guidance, so that the task is carried out easily and the results achieved in accordance with the goals set have the ability to carry out effective leadership.

Based on the description above, the authors feel interested in conducting research titled: " Effect of Effectiveness of School Leadership on Teacher Performance in Singkawang City Middle School. "The problems discussed in this study are; 1 ). How descriptive about the effectiveness of the leadership of the head of a state junior high school in the city of Singkawang?, 2) How descriptive about the performance of the state junior high school teacher 
in the city of Singkawang?, 3 ) How big is the effectivity of the effectiveness of the principal's leadership on the performance of the state junior high school teacher in the city of Singkawang?

This research used a quantitative research approach. According to Husna Asmara, ${ }^{3}$ quantitative research is research to solve problems based on relevant theories using quantitative data, because using quantitative data the analysis uses statistics. The method used is a survey method. Survey research generally aims to explain a general phenomenon based on the results of research on a number of samples. ${ }^{4}$ Thus the survey method was used to take samples from the population and by using a questionnaire as the main data collection instrument.

Based on the stated research objectives, this research is an explanatory research which is research that highlights the relationship between research variables and tests the hypothesis that has been formulated (Singaribun and Effendi, 1995). Based on various explanatory studies, the use of this type of research is appropriate to determine the relationship and influence of exogenous variables on a number of endogenous variables. The research location chosen was Singkawang City State Middle School.

\section{B. Research Results}

1. Description of respondent characteristics

From the results of the distribution of 82 questionnaire sheets, respondents can return all questionnaires. Before presenting the results of testing the hypothesis first presented the characteristics of respondents based on a distributed questionnaire, to describe in detail the circumstances of research respondents.

2. Analysis of respondent characteristics by gender

After tabulating data on the entire respondent's population, a description of respondents was obtained based on sex as follows:

Table 4.1

\begin{tabular}{|c|c|c|c|}
\hline No & sex & Quantity & Percentage (\%) \\
\hline 1 & Fimale & 52 & $63,41 \%$ \\
\hline 2 & Male & 30 & 36,59 \\
\hline & & 82 & $100 \%$ \\
\hline
\end{tabular}

Source: Primary data processed (2011)

\footnotetext{
${ }^{3}$ U. Husna Asmara, Penulisan Karya Ilmiah (Pontianak: Fahruna Bahasia, 2007).

${ }^{4}$ Bunyamin, Rancangan Penulisan Skripsi/Tesis Dalam Ilmu Sosial (Pontianak, 2010).
} 
M. Thaiyibi

Based on the table above, it can be seen that the majority of respondents are female ( $63.41 \%$ ), while the rest ( $36.59 \%$ ) are male. For education staff in Singkawang City Public Middle School more women than men.

3. Analysis of respondent characteristics by age

After tabulating data on all respondents, a description of respondents was obtained based on age as follows:

Table 4.2

Characteristics of respondents based on age

\begin{tabular}{|c|c|c|c|}
\hline No & Age & Quality & Percentage (\%) \\
\hline 1 & $20-30$ ys & 20 & 24,39 \\
\hline 2 & $31-40$ ys & 14 & 17,07 \\
\hline 3 & $41-50$ ys & 37 & 45,12 \\
\hline 4 & $51-60$ ys & 11 & 13,42 \\
\hline & & 82 & $100 \%$ \\
\hline
\end{tabular}

Data source: Primary data processed (2011)

From table 4.2 above shows the majority of respondents are in the age 41 - 50 years at $45.12 \%$ followed by the age of 20 - 30 years at $24.39 \%$, age $31-40$ years at $17.07 \%$ and aged 51 - 60 years at $1342 \%$. This shows that in the $41-50$ years or mid-career stage, this is where a person can con deteriorate.

4. Analysis of the characteristics of respondents based on years of service

After tabulating data on all respondents, a description of respondents based on years of service is obtained as follows:

Table 4.3

Characteristics of respondents based on years of service

\begin{tabular}{|c|c|c|c|}
\hline No & Years of Services & Quality & Percentage (\%) \\
\hline 1 & $\leq 5 \mathrm{ys}$ & 22 & 26,83 \\
\hline 2 & $6-15 \mathrm{ys}$ & 19 & 23,17 \\
\hline 3 & $>15 \mathrm{ys}$ & 41 & 50,00 \\
\hline & & 82 & $100 \%$ \\
\hline
\end{tabular}

Source: Primary data processed (2011)

From the table above it can be seen that the majority of respondents have a service life of 15 years and above. Educational staff at that time who had high expectations thought about a career ahead. 
5. Test results for validity and reliability

a. Validity test results

Validity test is used to determine the level of validity of the number instruments used in data collection. The way to do this is by analyzing items, where each question item's value is compared with the total number of questions for a variable by using the product moment correlation formula (Sugiono, 2004 ). To find out whether or not valid items must be compared with $\mathrm{r}$ table with the number of respondents $(\mathrm{n})=82$ respondents. From the product moment table ( 0.05 .82 ) obtained 0.22 . If r count $>$ from $r$ table then the item is valid, if $r$ count $<r$ table then the item is invalid. ${ }^{5}$

Based on the data obtained in the study, the results of testing the validity of the instrument can be seen in table.

Table 4.4

\begin{tabular}{|c|c|c|c|}
\hline Variable & Item & $\mathrm{r}$ & Information \\
\hline \multirow{17}{*}{$\begin{array}{l}\text { Leadership effectivity } \\
\text { Principal (x) }\end{array}$} & $\mathrm{X}_{1}$ & 0,368 & valid \\
\hline & $X_{2}$ & 0,428 & valid \\
\hline & $\mathrm{X}_{3}$ & 0,360 & valid \\
\hline & $\mathrm{X}_{4}$ & 0,487 & valid \\
\hline & $X_{5}$ & 0,397 & valid \\
\hline & $X_{6}$ & 0,371 & valid \\
\hline & $X_{7}$ & 0,385 & valid \\
\hline & $\mathrm{X}_{8}$ & 0,348 & valid \\
\hline & $\mathrm{X}_{9}$ & 0,404 & valid \\
\hline & $X_{10}$ & 0,285 & valid \\
\hline & $X_{11}$ & 0,156 & Tidak \\
\hline & $X_{12}$ & 0,488 & valid \\
\hline & $X_{13}$ & 0,388 & valid \\
\hline & $X_{14}$ & 0,455 & valid \\
\hline & $X_{15}$ & 0,354 & valid \\
\hline & $\mathrm{X}_{16}$ & 0,499 & valid \\
\hline & $X_{17}$ & 0,370 & valid \\
\hline
\end{tabular}

\footnotetext{
${ }^{5}$ Arif Pratisto, Statistik Menjadi Mudah dengan SPSS 17 (Yogyakarta: PT.Alek media Komputindo, 2009).
} 
M. Thaiyibi

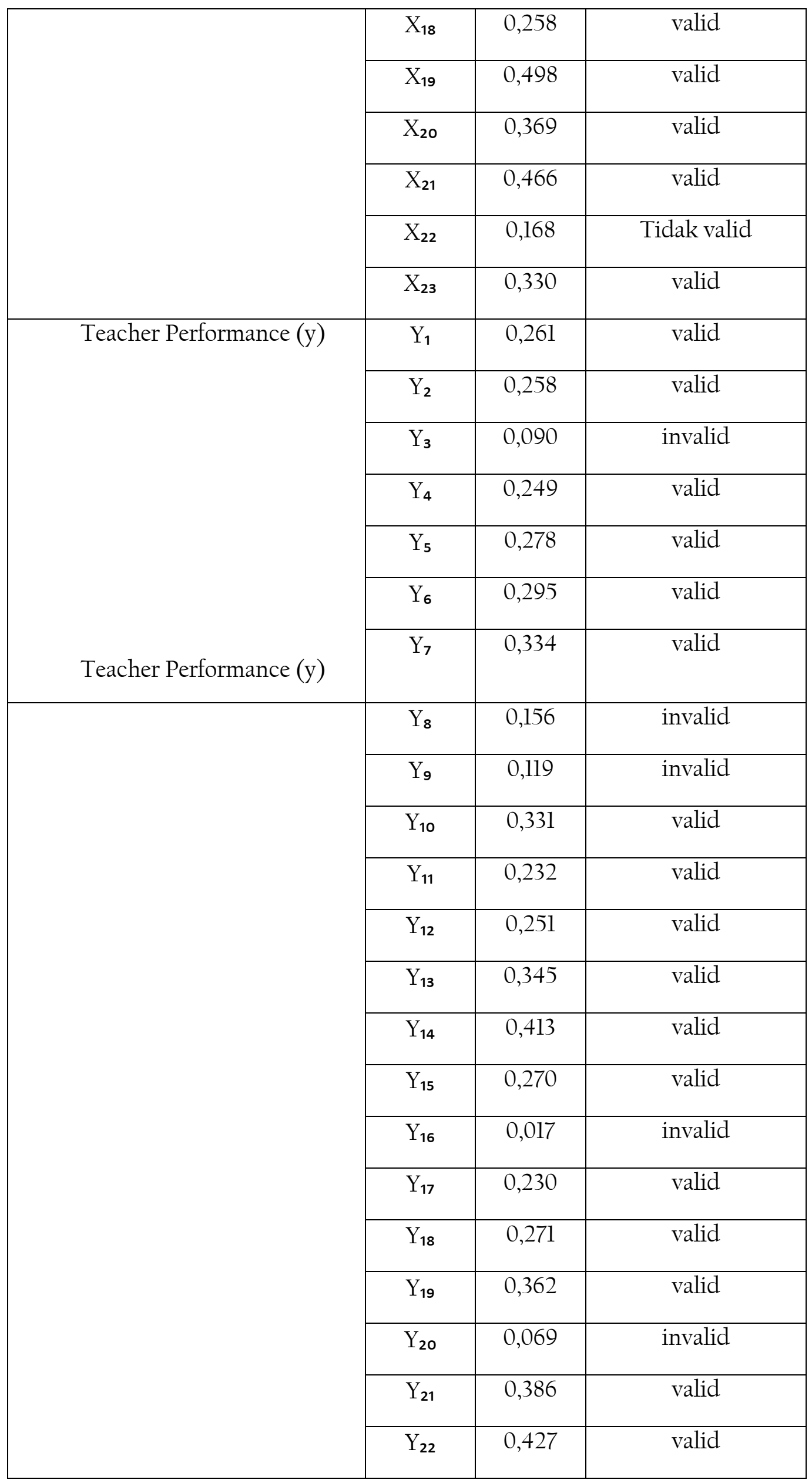




\begin{tabular}{|c|c|c|c|}
\cline { 2 - 3 } & $\mathrm{Y}_{23}$ & 0,425 & valid \\
\hline
\end{tabular}

Source: Primary data processed (2011)

b. Reliability test results

A measuring instrument is said to be reliable if it always gets the same results from the symptoms of measurement that does not change if done at different times. This reliability test was carried out using alpha Cronbach. The instrument is said to be reliable if it has a reliability of 0.60 or more. From the results of data processing, the alpha value of each variable can be seen in Table below:

Table 4.5

\begin{tabular}{|l|c|c|}
\hline \multicolumn{1}{|c|}{ Variables } & Alpha cronback & Information \\
\hline School Principal Leadership & 0,821 & valid \\
\hline Teacher Performance & 0,697 & valid \\
\hline
\end{tabular}

Source: Primary data processed (2011)

Based on the reliability test that has been done, the alpha coefficient of all variables shows the result $>0.60$. This means that the scale used can provide reliable measurement results.

6. Data analysis

a. Descriptive statistical analysis

Descriptive statistical analysis is intended to provide an overview of the independent variables and the dependent variable used in the study presented in the frequency distribution table. The frequency distribution displayed is a summary of respondents' responses to the statements contained in the questionnaire. The following is an explanation of each item and research variables based on respondents' responses.

b. The effectiveness variable of the principal's leadership (x)

The recapitulation results of the frequency distribution based on the answers collected from the questionnaire regarding the effectiveness of the principal's leadership variables can be seen in table below:

Table 4.6

Frequency distribution of headmaster effectiveness variables (x)

\begin{tabular}{|c|c|c|c|c|c|c|c|c|c|c|c|}
\hline \multirow{3}{*}{ Item } & \multicolumn{10}{|c|}{ Choice } & \multirow{3}{*}{ average } \\
\hline & \multicolumn{2}{|c|}{ l } & \multicolumn{2}{|c|}{2} & \multicolumn{2}{|c|}{3} & \multicolumn{2}{|c|}{4} & \multicolumn{2}{|c|}{5} & \\
\hline & $f$ & $\%$ & $\bar{f}$ & $\%$ & $\mathrm{f}$ & $\%$ & $f$ & $\%$ & 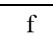 & $\%$ & \\
\hline$X_{1}$ & - & - & 一 & - & 7 & 8,54 & 60 & 73,17 & 15 & 18,29 & 4,1 \\
\hline
\end{tabular}


M. Thaiyibi

\begin{tabular}{|c|c|c|c|c|c|c|c|c|c|c|c|}
\hline$X_{2}$ & - & - & 1 & 1,22 & 7 & 8,54 & 66 & 80,48 & 8 & 9,76 & 4 \\
\hline$X_{3}$ & - & - & 1 & 1,22 & 12 & 14,63 & 61 & 74,39 & 8 & 9,76 & 3,9 \\
\hline $\mathrm{X}_{4}$ & - & - & 1 & 1,22 & 10 & 12,20 & 59 & 71,95 & 12 & 14,63 & 4 \\
\hline$X_{5}$ & - & - & 1 & 1,22 & 20 & 24,39 & 55 & 67,08 & 6 & 7,31 & 3,8 \\
\hline$X_{6}$ & - & - & - & - & 13 & 15,85 & 58 & 70,73 & 11 & 13,42 & 4 \\
\hline$X_{7}$ & - & - & - & - & 13 & 15,85 & 60 & 73,17 & 9 & 10,97 & 4 \\
\hline $\mathrm{X}_{8}$ & - & - & - & - & 7 & 8,54 & 62 & 75,61 & 13 & 15,84 & 4,1 \\
\hline$X_{9}$ & - & - & - & - & 7 & 8,54 & 67 & 81,70 & 8 & 9,76 & 4 \\
\hline$X_{10}$ & - & - & - & - & 14 & 17,07 & 55 & 67,08 & 13 & 15,85 & 4 \\
\hline$X_{11}$ & - & - & - & - & 11 & 13,42 & 60 & 73,16 & 11 & 13,42 & 4 \\
\hline$X_{12}$ & - & - & - & - & 6 & 7,31 & 54 & 65,86 & 22 & 26,83 & 4,2 \\
\hline$X_{13}$ & - & - & - & - & 9 & 10,98 & 60 & 73,16 & 13 & 15,85 & 4,1 \\
\hline$X_{14}$ & - & - & - & - & 11 & 13,42 & 58 & 70.73 & 13 & 15,85 & 4 \\
\hline$X_{15}$ & - & - & - & - & 9 & 10,97 & 58 & 70,73 & 15 & 18,30 & 4,1 \\
\hline$X_{16}$ & - & - & - & - & 6 & 7,31 & 57 & 69,52 & 19 & 23,17 & 4,1 \\
\hline$X_{17}$ & - & - & - & - & 14 & 17,07 & 53 & $\begin{array}{c}64,6 \\
4\end{array}$ & 15 & 18,29 & 4 \\
\hline$X_{18}$ & 1 & 1,22 & - & - & 8 & 9,76 & 56 & 68,29 & 17 & 20,73 & 4 \\
\hline$X_{19}$ & - & - & - & - & 7 & 8,54 & 54 & 65,85 & 21 & 25,61 & 4,2 \\
\hline$X_{20}$ & - & - & - & - & 19 & 23,17 & 46 & 56,10 & 17 & 20,73 & 4 \\
\hline$X_{21}$ & - & - & - & - & 18 & 21,95 & 40 & 48,78 & 24 & 29,27 & 4,1 \\
\hline$X_{22}$ & - & - & 3 & 3,66 & 6 & 7,32 & 50 & 60,98 & 23 & 28,04 & 4,1 \\
\hline$X_{23}$ & - & - & - & - & 7 & 8,54 & 43 & $\begin{array}{c}52,4 \\
4\end{array}$ & 32 & 39,02 & 4,3 \\
\hline & \multicolumn{10}{|c|}{ Mean (rata - rata ) } & 4,05 \\
\hline
\end{tabular}

Source: Primary data processed (2011)

Based on the frequency distribution table, the effectiveness variable of the headmaster's leadership with the leadership variable sub-oriented to the task, shows the average respondent's answer is at 4,0083 . Thus it can be concluded that the average teacher states that the leadership of the principal with the task orientation is already good and must be maintained both in terms of prioritizing the 
achievement of objectives, assessing the implementation of subordinate tasks, setting deadlines for carrying out tasks, setting certain standards on the task, giving instructions to subordinates and carrying out supervision of the task.

For the leadership sub-variable that is oriented to attention $\left(\mathrm{x}_{13}-\mathrm{x}_{23}\right)$ the average of all respondents' answers is at 4.0909. Thus it can be concluded that the average teacher states that the principal's leadership which is oriented to attention, tolerance needs to be maintained and improved even better. In general, the effectiveness of school principals leadership has an average score of 4.049 obtained from the questionnaire distributed. Thus the respondent's response to the effectiveness of the principal's leadership that they felt and saw was good.

c. Teacher performance variables (y)

The recapitulation results of frequency distribution based on the answers collected from the questionnaire regarding teacher performance variables can be seen in the following table berikut:

Table 4.7

Frequency distribution of teacher performance variables (y)

\begin{tabular}{|c|c|c|c|c|c|c|c|c|c|c|c|}
\hline \multirow{3}{*}{ Item } & \multicolumn{10}{|c|}{ Choices } & \multirow{3}{*}{ Mean } \\
\hline & \multicolumn{2}{|c|}{ l } & \multicolumn{2}{|c|}{2} & \multicolumn{2}{|c|}{3} & \multicolumn{2}{|c|}{4} & \multicolumn{2}{|c|}{5} & \\
\hline & $\mathrm{f}$ & $\%$ & $\mathrm{f}$ & $\%$ & $f$ & $\%$ & f & $\%$ & $\mathrm{f}$ & $\%$ & \\
\hline $\mathrm{Y}_{1}$ & - & - & - & - & 34 & 41,46 & 47 & 57,32 & l & 1,22 & 3,6 \\
\hline $\mathrm{Y}_{2}$ & - & - & - & - & 35 & 42,68 & 46 & 56,10 & 1 & 1,22 & 3,6 \\
\hline $\mathrm{Y}_{3}$ & - & - & 2 & $\begin{array}{c}2,4 \\
4\end{array}$ & 33 & $\begin{array}{c}40,2 \\
4\end{array}$ & 45 & 54,88 & 2 & 2,44 & 3,6 \\
\hline $\mathrm{Y}_{4}$ & - & - & - & - & 36 & 43,90 & 46 & 56,10 & - & - & 3,6 \\
\hline $\mathrm{Y}_{5}$ & - & - & - & - & 35 & 42,68 & 45 & 54,88 & 2 & 2,44 & 3,6 \\
\hline $\mathrm{Y}_{6}$ & - & - & - & - & 34 & 41,46 & 48 & 58,54 & - & - & 3,6 \\
\hline $\mathrm{Y}_{7}$ & - & - & - & - & 30 & 36,59 & 52 & 63,41 & - & - & 3,6 \\
\hline $\mathrm{Y}_{8}$ & - & - & - & - & 40 & 48,78 & 42 & 51,22 & - & - & 3,5 \\
\hline$Y_{9}$ & - & - & 1 & 1,22 & 45 & 54,88 & 36 & 43,90 & - & - & 3,4 \\
\hline $\mathrm{Y}_{10}$ & - & - & - & - & 32 & 39,02 & 49 & 59,76 & 1 & 1,22 & 3,6 \\
\hline $\mathrm{Y}_{11}$ & - & - & 1 & 1,22 & 26 & 31,71 & 51 & 62,20 & 4 & 4,88 & 3,7 \\
\hline $\mathrm{Y}_{12}$ & - & - & - & - & 28 & 34,14 & 51 & 62,20 & 3 & 3,66 & 3,7 \\
\hline
\end{tabular}




\begin{tabular}{|c|c|c|c|c|c|c|c|c|c|c|c|}
\hline $\mathrm{Y}_{13}$ & - & - & - & - & 27 & 32,93 & 53 & 64,63 & 2 & 2,44 & 3,7 \\
\hline $\mathrm{Y}_{14}$ & - & - & - & - & 32 & 39,02 & 48 & 58,54 & 2 & 2,44 & 3,6 \\
\hline $\mathrm{Y}_{15}$ & - & - & - & - & 33 & $\begin{array}{c}40,2 \\
4\end{array}$ & 48 & 58,54 & 1 & 1,22 & 3,6 \\
\hline $\mathrm{Y}_{16}$ & - & - & - & - & 37 & 45,12 & 43 & 52,4 & 2 & 2,44 & 3,5 \\
\hline $\mathrm{Y}_{17}$ & - & - & - & - & 36 & 43,90 & 46 & 56,10 & - & - & 3,5 \\
\hline $\mathrm{Y}_{18}$ & - & - & - & - & 31 & 37,80 & 50 & 60,98 & 1 & 1,22 & 3,6 \\
\hline $\mathrm{Y}_{19}$ & - & - & 1 & 1,22 & 30 & 36,58 & 50 & 60,98 & 1 & 1,22 & 3,6 \\
\hline $\mathrm{Y}_{20}$ & - & - & 3 & 3,66 & 38 & 46,34 & 40 & 48,78 & 1 & 1,22 & 3,5 \\
\hline $\mathrm{Y}_{21}$ & - & - & - & - & 27 & 32,92 & 43 & 52,4 & 2 & 2,44 & 3,7 \\
\hline $\mathrm{Y}_{22}$ & - & - & - & - & 29 & 35,36 & 49 & 59,76 & 4 & 4,88 & 3,7 \\
\hline $\mathrm{Y}_{23}$ & - & - & - & - & 30 & 36,58 & 45 & 54,88 & 7 & 8,54 & 3,7 \\
\hline & & & & & & & & & & & \\
\hline
\end{tabular}

Source: Primary data processed (2011)

Based on the frequency distribution table, the teacher performance variable with pedagogical subvariables ( $\left.\mathrm{y}_{1}, \mathrm{y}_{\mathbf{2}}, \mathrm{y}_{\mathbf{3}}, \mathrm{y}_{\mathbf{4}}, \mathrm{y}_{\mathbf{5}}, \mathrm{y}_{\mathbf{6}}, \mathrm{y}_{\mathbf{7}}, \mathrm{y}_{\mathbf{8}}, \mathrm{y}_{\mathbf{9}}, \mathrm{y}_{9}\right)$ shows the average respondent's answer at 3.57. Means it can help complete the increase in the average of student trainees that teachers do quite well, need to improve and improve again. For personality sub-variables $\left(\mathrm{y}_{11}, \mathrm{y}_{\mathbf{1 2}}, \mathrm{y}_{\mathbf{1 3}}\right)$ shows the average respondent's answer depends on the number 3.70. This means the importance of an average personality ability that is steady, noble, wise and authoritative as well as being an example of students needs to be equipped and improved in order to be better.

While professional subvariables ( $\mathrm{y}_{14}, \mathrm{y}_{15}, \mathrm{y}_{16}, \mathrm{y}_{17}, \mathrm{y}_{18}$ ) show the average respondent's answer based on number 3.56. This can help broaden the ability of teachers in mastering broad and deep material which is sufficient and needs to be developed and improved. Then for social competence subvariables ( $\mathbf{y}_{\mathbf{1 9}}, \mathrm{y}_{\mathbf{2 0}}, \mathrm{y}_{\mathbf{2 1}}, \mathrm{y}_{\mathbf{2 2}}$, y23) show the average ability to communicate and effectively with students, fellow teachers, parents, and the community around 3.64. This shows that teacher competency is quite good and must be improved and improved. 
In general the teacher performance variable has a score of 3.61

d. Hipotesis Hypothesis testing

The analytical method used to prove the hypothesis in this study using simple regression techniques.

Hypothesis :

There is a significant influence of school leadership leadership variables (x) on teacher performance variables (y). From the collected data, a helper table is provided as provided in, to calculate the figures obtained:

$$
\begin{aligned}
& \Sigma x=7643 \\
& \Sigma y=6800 \\
& \Sigma x^{2}=715155 \\
& \Sigma y^{2}=565502 \\
& \Sigma x y=635819 \\
& N \quad=\text { number of respondents (82 respondents) }
\end{aligned}
$$

(1) Calculates the formula $\mathrm{b}$ (regression coefficient for variable $\mathrm{x}$ )

$\mathrm{b}=\frac{\mathrm{n} \cdot \sum \mathrm{XY}-\sum \mathrm{X} \cdot \sum \mathrm{Y}}{\text { n. } \sum \mathrm{X}^{2}-\left(\sum \mathrm{X}\right)^{2}}$

n. $\Sigma x y-\sum x \cdot \sum y$

$$
82.635819-7643.6800
$$

$82.715155-(7643)^{2}$

$52137158-51972400$

181685

$58642710-58415449 \quad 227261$

$=\quad 0,725$

(2) Calculate the formula a

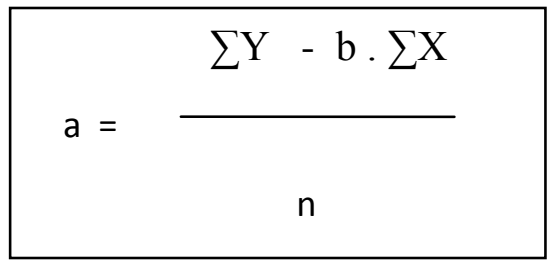


M. Thaiyibi

$=\frac{6800-5541,18}{82} \frac{1258,82}{82}$
$=15,35$

(3) Calculates a simple regression equation

$$
\begin{aligned}
& y=a+b x \\
& y=15,35+0,725 x
\end{aligned}
$$

(4) Make a regression equation:

(a) Calculate the average $x$ by the formula:

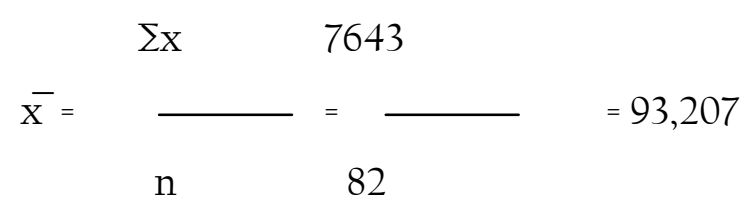

(b) Calculate mean Y by formula :
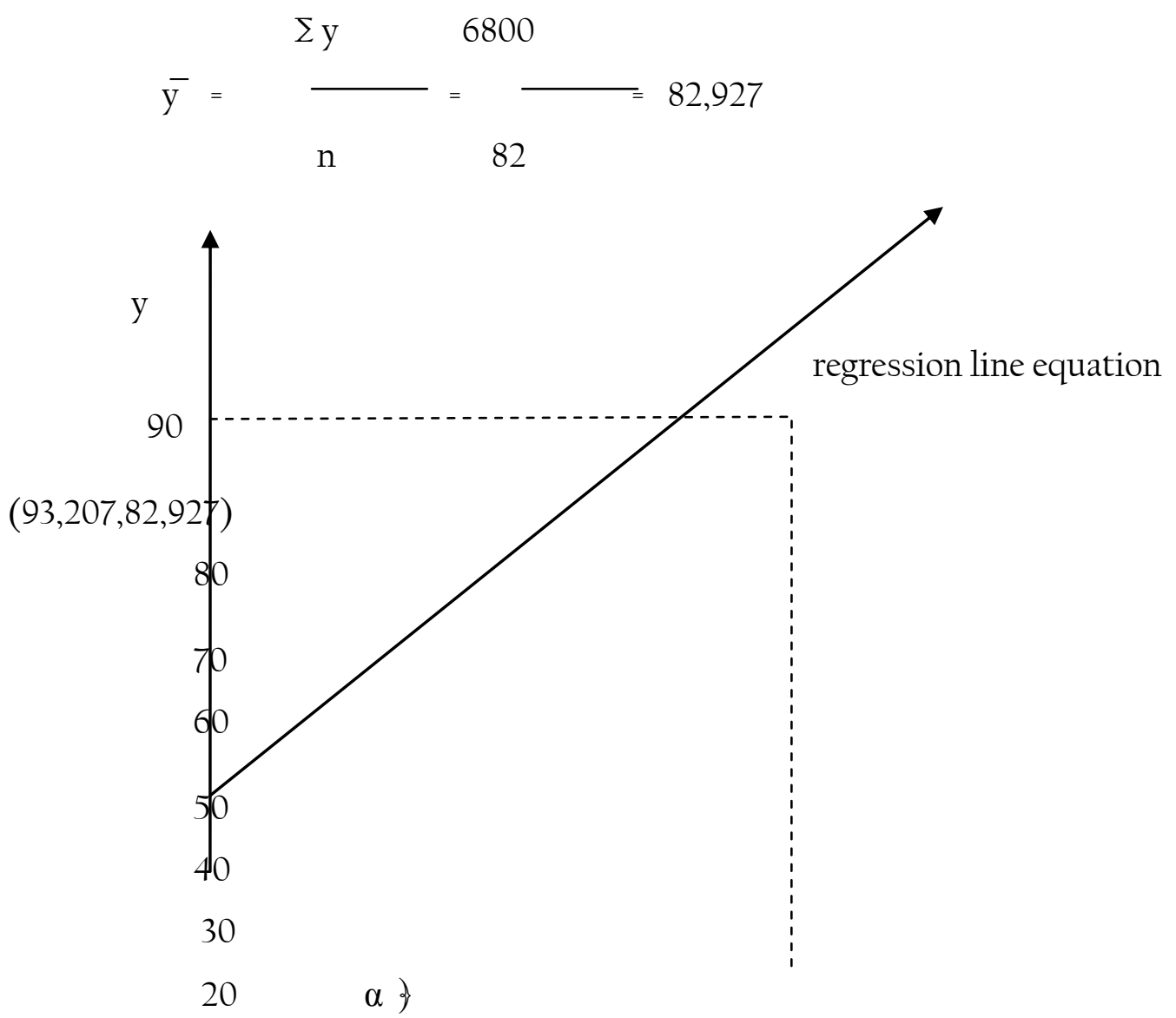

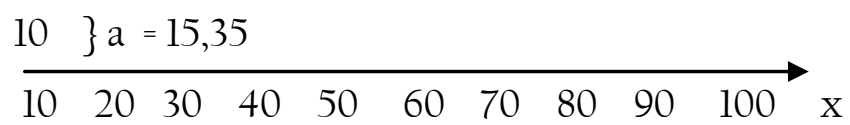


Test the significance with the following steps:

Step 1. Find the Number of Regression Squares (JK reg (a)) with the formula:

$$
\begin{aligned}
\mathrm{JK}_{\text {reg (a) }} & =\frac{(\Sigma \mathrm{Y})^{2}}{\mathrm{n}}=\frac{(6800)^{2}}{82}=\frac{46240000}{82} \\
& =563902,439
\end{aligned}
$$

Step 2 Find the Number of Regression Squares (JK Reg (b / a )) with the formula:

$$
(\Sigma X)(\Sigma Y)
$$

$$
\mathrm{JK} \operatorname{Reg}(\mathrm{b} / \mathrm{a})=\frac{\mathrm{b} \cdot\{\Sigma \mathrm{XY}-\}}{\mathrm{n}}
$$

$$
\begin{aligned}
& 7643.6800 \\
= & \frac{0,725\{635819}{82}- \\
= & 0,725\{2009,24\}=1456,699
\end{aligned}
$$

Step 3. Find the Number of Residue Squares (JK Res) with the formula:

$$
\begin{aligned}
\mathrm{JK}_{\text {Res }} & =\Sigma \mathrm{Y}^{2}-J \mathrm{~J}_{\operatorname{Reg}(\mathrm{b} / \mathrm{a})}-\mathrm{JK} \operatorname{Reg}(\mathrm{a}) \\
& =565502-1456,699-563902,439 \\
& =142,862
\end{aligned}
$$

Step 4. Find the Average Amount of Regression (JKReg (a)) using the formula :

$$
\mathrm{RJK}_{\operatorname{Reg}(\mathrm{a})}=\mathrm{JK}_{\mathrm{Reg}(\mathrm{a})}=563902,439
$$

Langkah 5. Mencari Rata - Rata Jumlah Kuadrat Regresi $\left(\mathrm{RJK} \mathrm{K}_{\mathrm{Reg}(\mathrm{b} / \mathrm{a})}\right)$ dengan rumus :

$$
\mathrm{RJK}_{\operatorname{Reg}(\mathrm{b} / \mathrm{a})}=\mathrm{JK}_{\mathrm{Reg}(\mathrm{b} / \mathrm{a})}=1456,699
$$

Step 6. Find the Average Number of Residual Squares (JKRes) with formula:

$$
\mathrm{RJK}_{\text {Res }}=\frac{\mathrm{JK_{ \text {Res } }}}{\mathrm{n}-2}=\frac{142,862}{80}=1,786
$$

Step 7. Test the significance with the formula:

$$
\begin{aligned}
\mathrm{F}_{\text {Hitung }}= & \underset{\text { RJK } K_{\text {eg(b/a) }}}{\text { RJK } K_{\text {Res }}}=\frac{1456,699}{1,786} \\
= & 815,621
\end{aligned}
$$

The rules of significance testing:

If $\mathrm{F}$ count $\geq \mathrm{F}$ table, then $\mathrm{HO}$ is rejected, it means that it is significant

F Calculate tabel $\mathrm{f}$ table, then $\mathrm{HO}$ is accepted meaning it is not significant 
M. Thaiyibi

With a significant level $(\alpha)=0.05$

Look for the $\mathrm{F}$ value table using table $\mathrm{F}$ with the formula:

$\left.\left.F_{\text {tabel }}=F_{[((1-)}\right)(d / k \operatorname{Reg}(b / a)),(d k \operatorname{Res})\right]$

$=\mathrm{F}_{[(0,95)(1,80)]}$

How to find the table $\mathrm{F}$ : number $\mathrm{l}$ = numerator

number 80 = denominator

F table: 3.96

It turns out that Fcount> F table then $\mathrm{HO}$ is rejected, it means significant

Regression Equations that are formed:

1. Systematically positive teacher performance with a value of 15.35 if variable $X=0$ or absent, the teacher's performance is still positive which might be influenced by inaccurate variables.

2. Regresi The value of the regression coefficient from the results of the study is 0.725 which means that mathematically each addition of 1 unit of influence of the variable $X$ (effectiveness of the leadership of the principal) will increase teacher performance by 0.725 units if the independent variable is considered permanent.

\section{c. Conclusions}

Based on the results of the analysis, testing the hypotheses and discussions that have been stated in the previous chapter, then the following conclusions and recommendations can be drawn:

1. Deskriptif Descriptive statistical analysis in general the results showed that the effectiveness of the school principal's leadership in the Singkawang City Junior High School (X) was good, while for the teacher performance variable (Y) it was good enough. This is indicated by the average score of the two variables respectively 4.05 and 3.61 .

2. The effectiveness of the principal's leadership has a significant influence on teacher performance. This is indicated by the $\mathrm{F}$. hit value of 815,621 with a regression coefficient of 0.725 units which mathematically each addition of 1 unit of leadership effectiveness variables will increase the teacher's performance by 0.725 units.

\section{Recommendation}

Based on the discussion and conclusions of the results of detailed research can be put forward suggestions - both for the development of science and for practical purposes. The suggestions proposed in this study are as follows:

1. The results showed that the effectiveness of the principal's leadership affected the performance of teachers in the State Junior High School in Singkawang City. Therefore, a leader is expected to always improve his performance related to improving teacher 
performance such as giving instructions to subordinates, prioritizing the achievement of objectives, assessing the implementation of subordinate tasks, fostering good cooperative relations, giving confidence to subordinates and so forth.

2. That in selecting prospective principals should be done selectively and strictly in accordance with applicable regulations to produce quality principals, without political elements or rewards therein in relation to the effective leadership of school principals.

3. For local governments, in this case the Office of Education should always facilitate the implementation of education and training for principals in developing their profession.

\section{d. References}

Arikunto, Suharsemi. (2002). Prosedur Penelitian. Suatu Pendekatan Praktek. Edisi Revisi. Rineka Cipta. Jakarta.

Arif, Pratisto. 2009. Statistik Menjadi Mudah dengan SPSS 17.PT.Alek media Komputindo. Yogyakarta.

Asep, Suryana Natawiria dan Riduan.2010. Statistik Bisnis. Alfabeta. Bandung.

Asnawi, Jamal Ma'mur. (2009) . Manajemen Pengelolaan dan kepemimpinan Pendidikan Profesional. Diva Pres. Yogyakarta.

Bunyamin. 2010. Rancangan Penulisan Skripsi/Tesis Dalam Ilmu Sosial, Pontianak.

Dessler, Gary.1998. Manajemen Sumber Daya Manusia. Edisi Bahasa Indonesia. Jilid 2 Alih Bahasa Benyamin Molan. PT Peruhallindo. Jakarta.

Fattah, Nanang. (2000). Landasan Manajemen Pendidikan. Bandung : PT. Remaja Rosda karya.

Husna Asmara ,U. 2007. Penulisan Karya Ilmiah. Fahruna Bahasia.Pontianak.

. 2008. Modul Umum Untuk Pendidikan dan Penelitian Profesional Guru. Untan. Pontianak.

Jones,R.Gareth.1995. Organisasi Theory. Text and Cases. Texas University Publishing Company. Boston.

Katter, John P dan James L.Heskett.1992. Corporade Culture and Performance. The free Press.New York.

Luthans,Fred.2001. Perilaku Organisasi. ANDI.Yogyakarta.

Masnur, Mushlich.2007. Kurikulum Tingkat Satuan Pendidikan Dasar Pemahaman dan Pengembangan. PT Bumi aksara. Jakarta.

Mc.Gregar. 2002. The Human Side Of Interprise. Karya Tulis.

Mulyasa, E.(2007). Menjadi Kepala Sekolah Profesional. PT.Remaja Rosda Karya.Bandung.

Mulyasa, E.(2007).Manajemen Berbasis Sekolah. PT.Remaja Rosda Karya. Bandung.

Peraturan Pemerintah No.28 tahun 1990 Tentang Tugas Tenaga Kependidikan.

Peraturan Menteri Pendidikan Nasional No. 28 tahun 2010 Tentang Penugasan Guru Sebagai Kepala Sekolah/Madrasah.

Riduan .(2007). Metode dan Teknik Menyusun Tesis. CV Alfabeta. Bandung.

Robbius,Stephen P.1996. Perilaku Organisasi. PT .Penhallindo. Jakarta.

Samana, (1994). Profesionalisme Keguruan. Kamsius. Yogyakarta.

Sjafri, Mangku Prawita. 2009. Horison Bisnis. Manajemen dan Sumber Daya Manusia. PT.Gramedia.Bogor.

Sugiyono.2005. Metode Penelitian Administrasi. Alfabeta.Bandung.

Sulistiyani, Ambar Teguh dan Rosidah. (2009). Manajemen Sumber Daya Manusia. Graha Ilmu.Yogyakarta. 
M. Thaiyibi

Umaedi.1999. Manajemen Peningkatan Mutu Berbasis Sekolah .Dirjen Peningkatan Mutu SLTP.Jakarta.

Undang - Undang No.14 tahun 2005 tentang Guru dan Dosen. Yogyakarta : Graha ilmu.

Undang - Undang No. 20 tahun 2003 tentang Sistem Pendidikan Nasional. (Undang - Undang Sisdiknas)

Uzer Usman, Moh. 2007. Menjadi Guru Profesional. PT.Remaja Rosda Karya. Bandung. 